\title{
Explaining the Attitude of Graduates of Agricultural Sector (Apprentices) from South Khorasan Province than Apprenticeship Plan
}

\author{
Golin Rakhshanipour ${ }^{1}$, Kourosh Rousta ${ }^{2}$ \\ ${ }^{1} \mathrm{MSc}$ Student of Agricultural Extension and Education, Islamic Azad University, Birjand branch \\ ${ }^{2}$ Assistant Professor, Islamic Azad University, Birjand branch, Department of Agricultural Extension and Education
}

\begin{abstract}
One of the impeditive that is in the university graduates employment' absence who are considered as the most important effective factors in the development of each society is the absence of sufficient experience in employing university thought in the field of function, and it is necessary to prepare skill and experience acquisition conditions for them in order to confront with this problem. University graduates apprenticeship as a successful and relatively modern toll enjoys much capabilities and capacities for creating or improving their technical and professional skills. The present research was carried out using measurement and questionnaire. The statistical population included 532 individual or person of graduate of agricultural sector(apprentices) and sample volume became distinct 84 individual using cochran formula that was increased to 300 individual for the purpose of increasing confidence percentage. Information gathering was conducted using relation simple random sampling. Obtained information and statistical data derived from questionnaires were tested according to the propounded purposes and theories. Data analysis was done using descriptive statistics method such as frequency, frequency percentage, mean, standard deviation and mode and in the descriptive statistics section spearman correlation coefficient statistics was employed for determining the correlation value between investigated variables. Significant levels testing and dependent variable grading mean comparison with independent variable was carried out using mann-whitney and kruskalwallis tests. The results indicate that the studied statistical population has a positive response toward training plan
\end{abstract}

Keywords: Attitude, Graduates of agricultural sector (apprentices),Apprenticeship plan

\section{Introduction}

Every year, many students enter to higher education system and graduate after some year and go towards market and this is in a condition that economic growth and jobcreation capacity of the society is not proportionate with students' growth. One of major reasons for this affair can be mentioned rather traditional context of job unites and low- level of used technologies in these units which cause these types of units don't attract suitably academic forces who usually tend to change and lead the unit room towards innovation and using from modern and efficient technics. Which this affair is as an excuse in hand of the managers of especially small and medium- size units to not accept them and disrupting the balance governed on the unit and its activities; whereas, lack of or slow process of academic group attraction in the body of current job especially in small and medium- size industries caused this concern that the process of innovation and entrepreneurship doesn't enjoy from an enough and suitable growth for developing sustainable job and this affair also caused to increase the gap between supply and demand of workforce (Zolfeghari and Salamati, 2005). The examinations show that there are any studies in respect of the attitudes of the graduates of agricultural sector (apprentices) from South Khorasan Province than apprenticeship plan. The current research aimed to collect necessary information on apprenticeship plan in viewpoint of graduated students in level of associate's, bachelors and master's degree of agricultural sector. Of course, conscious recognition of and positive attitude of the graduates of the agricultural sector (apprentices) to advantages of apprenticeship plan and finally their occupation is one of effective factors on quality promotion of future human resources of agricultural sector and is one of the most important discussion that should be considered well. The amount of graduates' cognition with apprenticeship plan and their purposes and what and how is their attitude than this plan show the main problem of this research so that based on its findings it can be opined by a scientific and research view on continuing or not continuing of this plan and or its improving, adjusting and changing. If the view of apprentices than this plan be positive and the defects and problems of this plan are identified, examined and solved, a suitable field may be provided for creating a job bed for the graduates of agricultural sector and may be effective in developing agricultural sector.

\section{Research Methodology}

The used research methodology is non-experimental applied one and in aspect of information gathering is descriptivesurvey one.

The dependent variable of research is "the attitude of graduates of agricultural sector (apprentices) from South Khorasan Province than apprenticeship plan". It should be mentioned that the scale of this variable is sequential.

The independent variables of this research included individual properties (age, gender, level of study, married status), job records, satisfaction level of salary, awareness level on plan, the type of used transportation during this course, ability level in applying and fitness of academic taught and work- satisfaction level of respondents, the place of apprenticeship, company motivation in apprenticeship plan, individuals' viewpoint than the executer of 


\section{International Journal of Science and Research (IJSR) ISSN (Online): 2319-7064 \\ Index Copernicus Value (2013): 6.14 | Impact Factor (2015): 6.391}

apprenticeship plan and individuals viewpoint than the properties of apprenticeship plan.

Statistical population of this research are graduated students of associate's, bachelor's and master's degree in the field of agriculture, natural resources and environment who have participated in apprenticeship plan in South Khorasan Province during 2005- 2010 that their numbers based on the statistics of agriculture engineering and natural resources system organization of South Khorasan Province are 532 students. For determining sample size the number of 30 questionnaires are selected randomly; the variance of considered attribute of population is determined and then the sample size is computed via Cochran formula as following:

$$
n=\frac{N(t . s)^{2}}{N(d)^{2}+(t . s)^{2}}
$$

Where:

n: sample size

$\mathrm{N}$ : statistical population size

$\mathrm{T}$ : $\mathrm{t}$ amount of student

S: standard deviation of population's considered attribute

$\mathrm{d}$ : possible accuracy is desirable. The following formula is used for getting $\mathrm{d}$ :

$$
d=\frac{t . s}{\sqrt{n}}
$$

Where: $\mathrm{n}$ is the sample size and $\mathrm{s}$ is standard deviation of population's considered attribute.

$$
\begin{gathered}
S=0.51 \\
d=\frac{1.96 \times 0.51}{\sqrt{30}}=0.1 \\
n=\frac{532(1.96 \times 0.51)^{2}}{532(0.1)^{2}+(1.96 \times 0.51)^{2}}=84
\end{gathered}
$$

This number is increased to 300 students for further accuracy.

The used sampling method is relation simple random. Field, document and library studies method, computerized searching and applying world network internet are used for information gathering.

In order to respond to the research problem, considered purposes and also hypotheses testing a questionnaire has been designed as a tool for collecting research data. The questions for measuring attitudes in questionnaire are in Likert scale and are arranged in a 5-part range from "completely disagree" to "completely agree" and "completely disagree" is equal to point (1) and "completely agree" is equal to point (5). The questionnaire included some questions related to individual properties, job records, satisfaction level of salary, awareness level, and worksatisfaction level of graduates of agricultural sector (apprentices), problems, obstacles and constraints of apprenticeship plan.

Cronbach alpha method was used for measuring the validity of questionnaire because the questions were close and in Likert scale. A number of 30 students were selected randomly from graduates'population of agricultural sector; after completing the related questionnaires the reliability of questionnaires were computed. The Cronbach's Alpha Coefficient was computed equal to 91 using from SPSS software.

\section{Findings and Discussion}

Average age of respondents is equal to 26 years old and its standard deviation is 2.86. The most age frequency of respondents is between 21-25 years old. Most of them meaning $66.7 \%$ of them (200 students) were female and $33.3 \%$ (100 students) were male. $56.3 \%$ of them (169 students) of them were married and $43.7 \%$ (131 students) were single. $16 \%$ of them (48 students) were holder of Associate's degree, 73.7\% (221 students) Bachelor's degree and $10.3 \%$ (31 students) Master's degree. Based on findings of this research $54.6 \%$ of respondents (134 students) studied in the field of Crop Science and Plant Breeding, Animal Science and Agricultural Education. The job record of many respondents $(75.7 \%)$ was less than 1 year. The amount of $47.3 \%$ of respondents (142 students) has participated in apprenticeship plan with motivation of gaining technical skills for entering to work market. $35 \%$ of under-studied students have passed their apprenticeship course in private sector related to their fields of study. $37.3 \%$ of them (112 students) have used from public vehicle for transportation during apprenticeship course. Awareness level of most of under- studied students on apprenticeship plan (41.3\%) were in medium level. The findings show that $35 \%$ of respondents (105 students) in medium level of awareness satisfied from received salary in apprenticeship plan. $35.7 \%$ of respondents (107 students) have estimated ability level in applying and fitness of academic taught with assigned works in medium level during apprenticeship plan. $37 \%$ of graduates of agricultural sector (111 apprentices) during apprenticeship plan satisfied from the assigned works in medium level. The viewpoint of under-studied individuals meaning 43.7\% (131 students) than the executer of apprenticeship plan was in high level.

The Interval of Standard Deviation from the Mean (ISDM) method has been used for determining the attitude of graduates of agricultural sector (apprentices) and grouping them in this respect. The findings resulted from this method show that $16.3 \%$ (49 students) had positive attitude, $36.3 \%$ (109 students) had relative positive attitude, 44.7\% (134 students) had relative negative attitude and 2.7\% (8 students) had negative attitude than apprenticeship plan.

Table 1: The attitude of respondents than apprenticeship plan

\begin{tabular}{|c|c|c|c|}
\hline Type of attitude & Frequency & Percentage & $\begin{array}{c}\text { Cumulative } \\
\text { percentage }\end{array}$ \\
\hline Negative & 8 & 2.7 & 2.7 \\
\hline Relative negative & 134 & 44.7 & 47.3 \\
\hline Relative positive & 109 & 36.3 & 83.7 \\
\hline Positive & 49 & 16.3 & 100 \\
\hline Total & 300 & 100 & --- \\
\hline
\end{tabular}

Correlation analyzing, regression and averages comparing have been used for inferential analysis of the research data. Table 2 shows research hypotheses, variables, scale of any variable and type of used statistical test, respectively. 


\section{International Journal of Science and Research (IJSR) \\ ISSN (Online): 2319-7064}

Index Copernicus Value (2013): 6.14 | Impact Factor (2015): 6.391

Table 2: Type of used test for testing hypotheses

\begin{tabular}{|c|c|c|c|c|c|}
\hline Hypothesis & $\begin{array}{c}\text { Variable } \\
1 \\
\end{array}$ & Scale & Variable 2 & Scale & Type of test \\
\hline $\begin{array}{l}\text { 1) There is a significant relationship between the attitude of } \\
\text { respondents than and their awareness level from apprenticeship } \\
\text { plan }\end{array}$ & Attitude & Ranking & $\begin{array}{l}\text { Awareness } \\
\text { level }\end{array}$ & Ranking & Spearman \\
\hline $\begin{array}{l}\text { 2) There is a significant relationship between the attitude of } \\
\text { respondents than apprenticeship plan and their age }\end{array}$ & Attitude & Ranking & Age & interval & Spearman \\
\hline $\begin{array}{l}\text { 3) There is a significant difference between the attitude of male } \\
\text { and female respondents than apprenticeship plan }\end{array}$ & Attitude & Ranking & Gender & Nominal & $\begin{array}{c}\text { Man } \\
\text { Whitney }\end{array}$ \\
\hline $\begin{array}{l}\text { 4) There is a significant difference between the attitude of } \\
\text { respondents than apprenticeship plan and their different levels of } \\
\text { study }\end{array}$ & Attitude & Ranking & $\begin{array}{l}\text { Level of } \\
\text { Study }\end{array}$ & Nominal & $\begin{array}{l}\text { Kroskal } \\
\text { Wallis }\end{array}$ \\
\hline $\begin{array}{l}\text { 5) There is a significant difference between the attitude of single } \\
\text { and married respondents than apprenticeship plan }\end{array}$ & Attitude & Ranking & $\begin{array}{c}\text { Married } \\
\text { status }\end{array}$ & Nominal & $\begin{array}{c}\text { Man } \\
\text { Whitney }\end{array}$ \\
\hline $\begin{array}{l}\text { 6) There is a significant relationship between the attitude of } \\
\text { respondents than apprenticeship plan and their job records }\end{array}$ & Attitude & Ranking & Job record & interval & Spearman \\
\hline $\begin{array}{l}\text { 7) There is a significant relationship between the attitude of } \\
\text { respondents than apprenticeship plan and their work- satisfaction } \\
\text { level }\end{array}$ & Attitude & Ranking & $\begin{array}{l}\text { Work- } \\
\text { satisfaction } \\
\text { level }\end{array}$ & Ranking & Spearman \\
\hline $\begin{array}{l}\text { 8) There is a significant difference between the attitude of } \\
\text { respondents than apprenticeship plan and their different fields of } \\
\text { study }\end{array}$ & Attitude & Ranking & $\begin{array}{l}\text { Field of } \\
\text { Study }\end{array}$ & Nominal & $\begin{array}{c}\text { Kroskal } \\
\text { Wallis }\end{array}$ \\
\hline $\begin{array}{l}\text { 9) There is a significant relationship between the attitude of } \\
\text { respondents than apprenticeship plan and their satisfaction level } \\
\text { from their salary and allowances }\end{array}$ & Attitude & Ranking & $\begin{array}{c}\text { Satisfaction } \\
\text { level from } \\
\text { salary }\end{array}$ & Ranking & Spearman \\
\hline $\begin{array}{l}\text { 10) There is a significant difference between the attitude of } \\
\text { respondents than apprenticeship plan and type of their used } \\
\text { transportation vehicle }\end{array}$ & Attitude & Ranking & $\begin{array}{l}\text { Type of } \\
\text { vehicle }\end{array}$ & Nominal & $\begin{array}{l}\text { Kroskal } \\
\text { Wallis }\end{array}$ \\
\hline $\begin{array}{l}\text { 11) There is a significant relationship between the attitude of } \\
\text { respondents than apprenticeship plan and their ability level in } \\
\text { applying and fitness of academic taught with assigned works }\end{array}$ & Attitude & Ranking & $\begin{array}{l}\text { Ability level } \\
\text { in applying } \\
\text { and fitness of } \\
\text { academic } \\
\text { taught }\end{array}$ & Ranking & Spearman \\
\hline $\begin{array}{l}\text { 12) There is a significant difference between the attitude of } \\
\text { respondents than apprenticeship plan and their apprenticeship } \\
\text { place }\end{array}$ & Attitude & Ranking & $\begin{array}{l}\text { Apprenticesh } \\
\text { ip place }\end{array}$ & Nominal & $\begin{array}{c}\text { Kroskal } \\
\text { Wallis }\end{array}$ \\
\hline $\begin{array}{l}\text { 13) There is a significant relationship between the attitude of } \\
\text { respondents than apprenticeship plan and their viewpoint than the } \\
\text { executer of apprenticeship plan }\end{array}$ & Attitude & Ranking & $\begin{array}{l}\text { Apprentices } \\
\text { viewpoint } \\
\text { than the } \\
\text { executer of } \\
\text { plan }\end{array}$ & Ranking & Spearman \\
\hline $\begin{array}{l}\text { 14) There is a significant difference between the attitude of } \\
\text { respondents than apprenticeship plan and their motivation to } \\
\text { participate in apprenticeship plan }\end{array}$ & Attitude & Ranking & $\begin{array}{l}\text { Motivation to } \\
\text { participate in } \\
\text { plan }\end{array}$ & Nominal & $\begin{array}{l}\text { Kroskal } \\
\text { Wallis }\end{array}$ \\
\hline $\begin{array}{l}\text { 15) There is a significant relationship between the attitude of } \\
\text { respondents than apprenticeship plan and their viewpoint than the } \\
\text { properties of apprenticeship plan }\end{array}$ & Attitude & Ranking & $\begin{array}{l}\text { Apprentices } \\
\text { viewpoint } \\
\text { than the } \\
\text { properties of } \\
\text { plan } \\
\end{array}$ & Ranking & Spearman \\
\hline
\end{tabular}

The findings resulted from data analyzing show that there is a significant and positive correlation between awareness level of graduates of agricultural sector (apprentices) of South Khorasan Province than apprenticeship plan and their attitude than apprenticeship plan. So, it can be said that the more awareness of graduates of agricultural sector (apprentices) than apprenticeship plan caused to the more positive attitude than apprenticeship plan and vice versa (table 3).

According to the obtained information there is a significant and positive relationship and correlation between the worksatisfaction level of graduates of agricultural sector (apprentices) of South Khorasan Province and their attitude than apprenticeship plan in level of less than $0.01\left(r_{s}=\right.$ 0.281 and $p=0.000)$; so we can conclude that the more work- satisfaction level caused to more suitable attitude than apprenticeship plan (table 3).

The findings resulted from this research show there is a significant and positive relationship and correlation between the salary- atisfaction level of graduates of agricultural sector (apprentices) of South Khorasan Province and their attitude than apprenticeship plan in level of $0.01\left(r_{s}=0.162\right.$ and $p=$ $0.005)$; so we can conclude that the more salary- satisfaction level caused to more positive attitude than apprenticeship plan (table 3).

The findings resulted from data analyzing show there is a significant and positive relationship and correlation between the ability level in applying and fitness of academic taught of respondents with assigned works during the course and their 


\section{International Journal of Science and Research (IJSR) \\ ISSN (Online): 2319-7064 \\ Index Copernicus Value (2013): 6.14 | Impact Factor (2015): 6.391}

attitude than apprenticeship plan in level of $0.01 \quad\left(r_{s}=\right.$ 0.324 and $p=0.000)$; so we can conclude that the fitness oof academic taught of graduates of agricultural sector (apprentices) of South Khorasan Province with assigned works during the course have effected their attitude than apprenticeship plan and this efficacy is positive (table 3 ).

According to the obtained information there is a significant and positive relationship and correlation between the viewpoint of respondents than apprenticeship plan and their attitude than apprenticeship plan in level of $0.01 \quad\left(r_{s}=\right.$ 0.267 and $p=0.000)$; so we can conclude that the viewpoint of respondents than apprenticeship planhave effected their attitude than apprenticeship plan and this efficacy is positive (table 3 ).

The findings resulted from this research show there is a significant and positive relationship and correlation between the viewpoint of graduates of agricultural sector (apprentices) of South Khorasan Province than the properties of apprenticeship plan and their attitude than apprenticeship plan in level of $0.01\left(r_{s}=0.403\right.$ and $p=$ $0.000)$; so we can conclude that the viewpoint of respondents than the properties of apprenticeship plan have effected their attitude than apprenticeship plan and this efficacy is positive (table 3 ).

Table 3: Obtained correlation coefficients between dependent variables and respondents' attitude than apprenticeship plan

\begin{tabular}{|c|c|c|c|}
\hline Row & Dependent variable & $\begin{array}{c}\text { Correlation } \\
\text { coefficient }\end{array}$ & $\begin{array}{c}\text { Significant } \\
\text { level }\end{array}$ \\
\hline 1 & Age & 0.018 & 0.757 \\
\hline 2 & Job records & 0.001 & 0.980 \\
\hline 3 & Awareness level & 0.293 & 0.000 \\
\hline 4 & Work satisfaction level & 0.281 & 0.000 \\
\hline 5 & Salary satisfaction level & 0.162 & 0.005 \\
\hline 6 & $\begin{array}{c}\text { Ability level in } \\
\text { applying and fitness of } \\
\text { academic taught with } \\
\text { assigned works }\end{array}$ & 0.324 & 0.000 \\
\hline 7 & $\begin{array}{c}\text { The viewpoint of } \\
\text { respondents than the } \\
\text { executer of } \\
\text { apprenticeship plan }\end{array}$ & 0.267 & 0.000 \\
\hline 8 & $\begin{array}{c}\text { The viewpoint of } \\
\text { respondents than the } \\
\text { properties of } \\
\text { apprenticeship plan }\end{array}$ & 0.403 & 0.000 \\
\hline \multicolumn{3}{|c|}{} & \\
\hline & \multicolumn{1}{|c|}{} \\
\hline
\end{tabular}

The findings resulted from data analyzing show there is a significant difference between the attitude of female respondents (ranking average: 142.21) and the attitude of male respondents (ranking average: 167.08) in level of 0.05 $(s i g=0.012)$; it is seemed that the male respondents have more positive attitude than apprenticeship plan.

Table 4: Comparing the attitude of male and female respondents than apprenticeship plan using from Man-

$$
\text { Whitney test }
$$

\begin{tabular}{|c|c|c|c|c|c|}
\hline \multirow{2}{*}{$\begin{array}{c}1^{\text {st }} \\
\text { variable }\end{array}$} & \multirow{2}{*}{ Level } & \multicolumn{4}{|c|}{$\begin{array}{c}2^{\text {nd }} \text { variable: the attitude of respondents } \\
\text { than apprenticeship plan }\end{array}$} \\
\cline { 3 - 5 } & & $\mathrm{n}$ & $\mathrm{m}$ & $\mathrm{u}$ & $\mathrm{p}$ \\
\hline \multirow{2}{*}{ Gender } & Female & 200 & 142.21 & \multirow{2}{*}{8342.5} & \multirow{2}{*}{0.012} \\
\cline { 2 - 4 } & Male & 100 & 167.08 & \\
\hline
\end{tabular}

$\mathrm{n}$ : frequency $\mathrm{m}$ : ranking average $\mathrm{u}$ : Man- Whitney test $\mathrm{p}$ : significance

The findings resulted from respondents' level of study show there is a significant difference between the average attitude of respondents in the level of associate's degree (ranking average: 181.19), bachelor's degree (ranking average: 146.46) and master's degree (ranking average: 131.71) than the apprenticeship plan in level of $0.01(\mathrm{sig}=0.010)$.

Table 5: Comparing the attitude of respondents' different level of study than apprenticeship plan using from Kruskal

\begin{tabular}{|c|c|c|c|c|c|}
\hline \multicolumn{6}{|c|}{ Wallis test } \\
\hline \multirow{2}{*}{$\begin{array}{c}1^{\text {st }} \\
\text { variable }\end{array}$} & \multirow[t]{2}{*}{ Level } & \multicolumn{4}{|c|}{$\begin{array}{l}2^{\text {nd }} \text { variable: the attitude of } \\
\text { respondents than apprenticeship } \\
\text { plan }\end{array}$} \\
\hline & & $\mathrm{n}$ & $\mathrm{m}$ & $\begin{array}{c}\text { Chi- } \\
\text { square }\end{array}$ & $\mathrm{p}$ \\
\hline \multirow{3}{*}{$\begin{array}{l}\text { Level } \\
\text { of } \\
\text { study }\end{array}$} & Associate's degree & 48 & 181.19 & \multirow{3}{*}{9.233} & \multirow{3}{*}{0.010} \\
\hline & Bachelor's degree & 221 & 146.46 & & \\
\hline & Master's degree & 31 & 131.81 & & \\
\hline
\end{tabular}

$\mathrm{n}$ : frequency $\mathrm{m}$ : ranking average $\mathrm{p}$ : significance

The findings resulted from data analyzing show that there is not a significant difference between single and married respondents and their attitudes than apprenticeship plan. $(\operatorname{sig}=0.676)$

Table 6: Comparing the attitude of married and single respondents than apprenticeship plan using from ManWhitney test

\begin{tabular}{|c|c|c|c|c|c|}
\hline \multirow{2}{*}{$1^{\text {st }}$ variable } & \multirow{2}{*}{ Level } & \multicolumn{4}{|c|}{$\begin{array}{c}2^{\text {nd }} \text { variable: the attitude of respondents } \\
\text { than apprenticeship plan }\end{array}$} \\
\cline { 3 - 5 } & & $\mathrm{n}$ & $\mathrm{m}$ & $\mathrm{u}$ & $\mathrm{p}$ \\
\hline $\begin{array}{c}\text { Marriage } \\
\text { status }\end{array}$ & Single & 131 & 148.29 & \multirow{2}{*}{10780.5} & 0.676 \\
\cline { 2 - 4 } & Married & 169 & 152.21 & & \\
\hline
\end{tabular}

$\mathrm{n}$ : frequency $\mathrm{m}$ : ranking average $\mathrm{u}$ : Man- Whitney test $\mathrm{p}$ : significance

The information resulted from data analyzing shows that there is no significant difference between respondents' field of study and their attitudes than apprenticeship plan.

Table 7: Comparing the attitude of respondents based on different fields of study using from Kruskal Wallis test

\begin{tabular}{|c|c|c|c|c|c|}
\hline $\begin{array}{c}1^{\text {st }} \\
\text { variable }\end{array}$ & Level & $\mathrm{n}$ & $\mathrm{m}$ & $\begin{array}{l}\text { Chi- } \\
\text { square }\end{array}$ & $\mathrm{p}$ \\
\hline \multirow{12}{*}{$\begin{array}{l}\text { Field of } \\
\text { study }\end{array}$} & $\begin{array}{l}\text { Agricultural } \\
\text { Education }\end{array}$ & 37 & 131.38 & \multirow{12}{*}{15.14} & \multirow{12}{*}{0.176} \\
\hline & $\begin{array}{l}\text { Crop Science and } \\
\text { Plant Breeding }\end{array}$ & 66 & 138.70 & & \\
\hline & Animal Science & 61 & 151.85 & & \\
\hline & Natural Resources & 39 & 147.41 & & \\
\hline & Horticulture & 22 & 174.36 & & \\
\hline & Food Industry & 17 & 196.29 & & \\
\hline & Plant Pathology & 11 & 160.73 & & \\
\hline & Irrigation & 6 & 116 & & \\
\hline & Mechanization & 10 & 164.20 & & \\
\hline & $\begin{array}{c}\text { Plant and } \\
\text { Pharmaceutical } \\
\text { Productions } \\
\end{array}$ & 21 & 171.55 & & \\
\hline & Soil science & 5 & 124.10 & & \\
\hline & $\begin{array}{l}\text { Agricultural } \\
\text { Economy }\end{array}$ & 5 & 124.10 & & \\
\hline
\end{tabular}

$\mathrm{n}$ : frequency $\mathrm{m}$ : ranking average $\mathrm{p}$ : significance 


\section{International Journal of Science and Research (IJSR) \\ ISSN (Online): 2319-7064 \\ Index Copernicus Value (2013): 6.14 | Impact Factor (2015): 6.391}

The results from information analyzing show that there is a significant difference between the type of used vehicle by respondents and their attitudes than apprenticeship plan. The resulted findings from data analyzing by Kruskal Wallis are representative of significant difference in level 0.01 (sig: 0.002) between the attitudes of respondents who have used from personal vehicle (ranking average: 162.99), employer vehicle (ranking average: 179.68), rental vehicle (ranking average: 120.04) and public vehicle (ranking average: 141.73) for transportation during apprenticeship plan.
Table 8: Comparing the attitude of respondents based on the used vehicle

\begin{tabular}{|c|c|c|c|c|c|}
\hline \multirow[t]{2}{*}{$\begin{array}{c}1^{\text {st }} \\
\text { variable }\end{array}$} & \multirow[t]{2}{*}{ Level } & \multicolumn{4}{|c|}{$\begin{array}{l}2^{\text {nd }} \text { variable: the attitude of } \\
\text { respondents than } \\
\text { apprenticeship plan }\end{array}$} \\
\hline & & $\mathrm{n}$ & $\mathrm{m}$ & $\mathrm{u}$ & $\mathrm{p}$ \\
\hline \multirow{4}{*}{$\begin{array}{c}\text { The } \\
\text { used } \\
\text { vehicle }\end{array}$} & Personal vehicle & 109 & 162.99 & \multirow[b]{2}{*}{14.91} & \multirow[b]{2}{*}{0.002} \\
\hline & $\begin{array}{l}\text { Employer } \\
\text { vehicle }\end{array}$ & 34 & 179.68 & & \\
\hline & Rental vehicle & 45 & 120.04 & & \\
\hline & Public vehicle & 112 & 141.73 & & \\
\hline
\end{tabular}

$\mathrm{n}$ : frequency $\mathrm{m}$ : ranking average $\mathrm{p}$ : significance

The results from data analyzing show that there is any significant difference (sig: 0.356) between the average attitudes of respondents whose their place of apprenticeship had been a public sector related to their fields of study (ranking average: 158.53), public sector unrelated to their fields of study (ranking average: 150.61), private sector related to their fields of study (ranking average: 157.60), private sector unrelated to their fields of study (ranking average: 114.29), cooperative sector related to their fields of study (ranking average: 146.25) and cooperative sector unrelated to their fields of study (ranking average: 144.94).

Table 9: Comparing the attitude of respondents based on the place of apprenticeship using from Kruskal Wallis test

\begin{tabular}{|c|c|c|c|c|c|}
\hline \multirow[t]{2}{*}{$1^{\text {st }}$ variable } & \multirow[t]{2}{*}{ Level } & \multicolumn{4}{|c|}{$\begin{array}{l}2^{\text {nd }} \text { variable: the attitude of respondents than } \\
\text { apprenticeship plan }\end{array}$} \\
\hline & & $\mathrm{n}$ & $\mathrm{m}$ & $\mathrm{u}$ & $\mathrm{p}$ \\
\hline \multirow{6}{*}{$\begin{array}{l}\text { The place of } \\
\text { apprenticeship }\end{array}$} & Public sector related to field of study & 51 & 158.53 & \multirow{6}{*}{5.52} & \multirow{6}{*}{0.356} \\
\hline & Public sector unrelated to field of study & 22 & 150.61 & & \\
\hline & Private sector related to field of study & 105 & 157.60 & & \\
\hline & Private sector unrelated to field of study & 19 & 114.29 & & \\
\hline & Cooperative sector related to field of study & 79 & 146.25 & & \\
\hline & Cooperative sector unrelated to field of study & 24 & 144.94 & & \\
\hline
\end{tabular}

$\mathrm{n}$ : frequency $\mathrm{m}$ : ranking average $\mathrm{p}$ : significance

The results from data analyzing show that there is a significant difference in level 0.01 between the motivation to participate in apprenticeship plan from graduates of agricultural sector (apprentices) of SoutherKhorashan Province and their attitudes than apprenticeship plan. The resulted findings from data analyzing by Kruskal Wallis are representative of a significant difference between the attitudes of respondents who have participated in apprenticeship plan with the motivation of not finding favorite job (ranking average: 133.06), personal interest (ranking average: 167.88), acquiring technical skills and entering to work market (ranking average: 166.84) and earn money in apprenticeship plan (ranking average: 126.89).

Table 10: Comparing the attitude of respondents based on the motivation to participate in apprenticeship plan using from Kruskal Wallis test

\begin{tabular}{|c|c|c|c|c|c|}
\hline \multirow[t]{2}{*}{$1^{\text {st }}$ variable } & \multirow[t]{2}{*}{ Level } & \multicolumn{4}{|c|}{$\begin{array}{l}2^{\text {nd }} \text { variable: the attitude of respondents than } \\
\text { apprenticeship plan }\end{array}$} \\
\hline & & $\mathrm{n}$ & $\mathrm{m}$ & $\mathrm{u}$ & $\mathrm{p}$ \\
\hline \multirow{4}{*}{ Motivation } & Not- finding favorite job & 89 & 133.06 & \multirow{4}{*}{15.18} & \multirow{4}{*}{0.002} \\
\hline & Personal interest & 21 & 167.88 & & \\
\hline & Technical skills acquisition and entering to work market & 142 & 166.84 & & \\
\hline & Earn money & 48 & 126.89 & & \\
\hline
\end{tabular}

$\mathrm{n}$ : frequency $\mathrm{m}$ : ranking average $\mathrm{p}$ : significance

The stepwise regression method has been used for examining the relationship of synchronicity between dependent variable and independent variables and analyzing that what variables are effective on the attitudes of graduates of agricultural sector (apprentices). The results of regression analyzing have been shown in tables (11) and (12). 


\section{International Journal of Science and Research (IJSR) \\ ISSN (Online): 2319-7064 \\ Index Copernicus Value (2013): 6.14 | Impact Factor (2015): 6.391}

Table 11: multiple correlation coefficients, multiple R square, adjusted R square in different steps of regression

\begin{tabular}{|c|c|c|c|c|c|}
\hline Step & Dependent variable & $\begin{array}{c}\text { Multiple } \\
\text { Correlation } \\
\text { Coefficient (R) }\end{array}$ & $\begin{array}{c}\text { Multiple } \\
\mathrm{R} \\
\text { Square }\end{array}$ & $\begin{array}{c}\text { Adjusted } \\
\mathrm{R} \text { Square } \\
\left(\mathrm{R}^{2}\right)\end{array}$ & $\begin{array}{c}\text { Std. Error of } \\
\text { the Estimate }\end{array}$ \\
\hline 1 & The properties of apprenticeship plan & 0.413 & 0.171 & 0.168 & 0.709 \\
\hline 2 & Ability level in applying and fitness of academic taught with assigned \\
works & 0.449 & 0.202 & 0.196 & 0.697 \\
\hline 3 & The viewpoint of apprentices than the executer of apprenticeship plan & 0.468 & 0.219 & 0.211 & 0.690 \\
\hline 4 & Ability level of apprentices than apprenticeship plan & 0.480 & 0.231 & 0.220 & 0.687 \\
\hline
\end{tabular}

Table 12: Effect of effective variables on the attitudes of graduates of agricultural sector (apprentices)

\begin{tabular}{|c|c|c|c|c|}
\hline Independent Variable & $\mathrm{B}$ & $\mathrm{Beta}$ & $\mathrm{T}$ & $\mathrm{P}$ \\
\hline Constant & 0.567 & - & 2.293 & 0.023 \\
\hline $\begin{array}{c}\text { The properties of } \\
\text { apprenticeship plan }\end{array}$ & 0.252 & 0.237 & 3.770 & 0.000 \\
\hline $\begin{array}{c}\text { Ability level in applying and } \\
\text { fitness of academic taught with } \\
\text { assigned works }\end{array}$ & 0.116 & 0.160 & 2.720 & 0.007 \\
\hline $\begin{array}{c}\text { The viewpoint of apprentices } \\
\text { than the executer of } \\
\text { apprenticeship plan }\end{array}$ & 0.132 & 0.144 & 2.582 & 0.010 \\
\hline $\begin{array}{c}\text { Awareness level of apprentices } \\
\text { than apprenticeship plan }\end{array}$ & 0.118 & 0.120 & 2.093 & 0.037 \\
\hline
\end{tabular}

The results of the above mentioned tables show that the variable of respondents' viewpoint than the properties of apprenticeship plan was as the $1^{\text {st }}$ variable entered to equation. This variable explained $16.8 \%$ of dependent variable changes of the attitude. In $2^{\text {nd }}$ step, the variable of "ability level in applying and fitness of academic taught with assigned works" entered to equation. This variable in turn explained the amount of $2.8 \%$ of dependent variable changes of the attitude. In $3^{\text {rd }}$ step, the variable of "apprentices' viewpoint than the executer of apprenticeship plan" entered to the equation. This variable explained the amount of $1.5 \%$ of dependent variable changes of the attitude. In the last step, the variable of "awareness level of apprentices than apprenticeship plan" entered to the equation that this variable in turn explained the amount of $0.9 \%$ of dependent variable changes of the attitude. After the four aforesaid variables entered to the equation the operation was stopped. In fact, the amount of $22 \%$ of dependent variable changes of the attitude were explained by these four variables and other changes are related to the factors which were not entered in this equation. Linear equation resulted from regression analysis is as follows:

$$
\begin{aligned}
Y=0.252\left(x_{1}\right)+ & 0.116\left(x_{2}\right)+0.224\left(x_{3}\right)+0.118\left(x_{4}\right) \\
& +0.567
\end{aligned}
$$

Where:

Y: dependent variable (the attitude of graduates of agricultural sector (apprentices))

$\mathrm{x}_{1}$ : the viewpoint of graduates of agricultural sector (apprentices) than the properties of apprenticeship plan $\mathrm{x}_{2}$ : ability level in applying and fitness of academic taught with assigned works

$\mathrm{x}_{3}$ : the viewpoint of graduates of agricultural sector (apprentices) than the executer of apprenticeship plan $\mathrm{x}_{4}$ : awareness level of apprentices than apprenticeship plan

Disadvantages of apprenticeship plan in viewpoint of graduates of agricultural sector (apprentices)
Regarding to the necessity of awareness in viewpoint of graduates of agricultural sector (apprentices) from South Khorasan Province, their views have been adapted on disadvantages of apprenticeship plan in frame of open questions of questionnaire in which the frequency percentage are respectively as follows: 1) low wages, 2) lack of fitness and coordination between the assigned works and field of study and lack of determined duties description, 3) lack of job records' insurance, 4) lack of obligation to attract apprentices, 5) lack of enough supervision, 6) short term course duration, 7) lack of attention to transportation problems, 8) lack of lateral supports after finishing the project.

\section{Conclusions}

Based on the research statistical results and for improving and promoting qualitative level of apprenticeship plan and specially solving some current problems, the following suggestions and strategies can be offered:

- $\quad$ Regarding to the more effective role of awareness level of graduates of agricultural sector (apprentices) than apprenticeship plan and their attitudes than the mentioned project that the findings resulted from this research show well, it is suggested that a briefing session should be held for increasing their awareness level on apprenticeship plan before dispatching graduates of agricultural sector (apprentices) for doing apprenticeship plan.

- The results of this study show a significant difference between the motivation to participate in apprenticeship plan of graduates of agricultural sector (apprentices) and their attitudes than apprenticeship plan and the ranking average of individuals who participate in apprenticeship plan with personal motivation are more than others. So, it is suggested that the training courses should be held for encouraging them on apprenticeship plan.

\section{Acknowledgment}

The authors are grateful to HamedNekoubin for the assistance with the field studies.

\section{References}

[1] Karbasi, A., Daneshvar, M. (1990).Examining occupation status in agriculture sector of Khorasan Province in $3^{\text {rd }}$ development plan.

[2] Modarrest university, paes: 365- 364.

[3] Transportation Ministry (1993), apprenticeship planapprentice guide.Education and consultation assistance. Available on www.mrt.ir

[4] TorabiMehrbani, M. (1997).Apprenticeship for academic students' Job Readiness. Available in www.atcce.com 


\section{International Journal of Science and Research (IJSR) \\ ISSN (Online): 2319-7064}

Index Copernicus Value (2013): 6.14 | Impact Factor (2015): 6.391

[5] Zolfaghari, Salamati, F (2005), take a look at apprenticeship plan of academic graduates in $4^{\text {th }}$ development plan. The set of higher education essays and education system of Iran. $2^{\text {nd }}$ conference of Iran' occupation and education system of Iran. Tehran: Tarbiat 